Bangladesh J. Bot. 44(1): 97-101, 2015 (March)

\title{
EFFECTS OF DIFFERENT SOWING DATES ON THE PHENOLOGY AND ACCUMULATED HEAT UNITS IN THREE RAPESEED (BRASSICA CAMPESTRIS L.) VARIETIES
}

\author{
Mst Towhida AKhter ${ }^{1 *}$, MA Mannan, PB Kundu And NK Paul
}

Department of Botany, University of Rajshahi, Rajshahi-6205, Bangladesh

Key words: Phenology, Growing degree days, Heat use efficiency, Pheno-thermal index

\begin{abstract}
A field experiment was carried out to study the effect of sowing dates on phenology and accumulated heat units of rapeseed (Brassica campestris L.). Seeds of three varieties (BARI Sarisha-14, BINA Sarisha-5 and BINA Sarisha-6) were sown on four different dates from October to December $\left(\mathrm{S}_{1}-18\right.$ October, $\mathrm{S}_{2}-2$ November, $S_{3}-17$ November and $S_{4}-3$ December). The results indicated that the number of days required to attain different phenological stages decreased with delay in sowing. For all the phenological stages, $\mathrm{S}_{1}$ required higher heat units than that of other sowings. The plants of $S_{1}$ used heat more efficiently than $S_{2}, S_{3}$ and $\mathrm{S}_{4}$. At the earlier phenological stages, phenothermal index decreased with delay in sowing, but increased at the later stages.
\end{abstract}

\section{Introduction}

Rapeseed is basically a short-day crop of the temperate region and requires relatively low temperature for satisfactory growth. Among the climatic factors, temperature plays a key role in determining sowing time and consequently the duration of different phenophases and thus the crop productivity (Tewari and Singh 1993). Influence of temperature on phenology and yield of crop plants can be studied under field conditions through the accumulated heat units system or growing degree-days (GDD) (Chakravarty and Sastry 1983, Rajput et al. 1987, Bishroi et al. 1995). Though accumulation of degree-days for each developmental stage is relatively constant and independent of sowing date, crop variety may modify it considerably (Phadnawis and Saini 1992). Further, delay in sowing may not permit proper vegetative growth of the crop and it may face high temperature at its later growth stages leading to forced maturity and low productivity. Hence, the present investigation was undertaken to study the effect of sowing date and crop variety on phenological development, growth and productivity of rapeseed under mild and short winter condition of Bangladesh.

\section{Materials and Methods}

The experiment was carried out at the experimental field of Rajshahi University Campus (AgroEcological Zone 11), Bangladesh (24 $75^{\prime} \mathrm{N}$ latitude and $90^{\circ} 50^{\prime} \mathrm{E}$ longitude) during October, 2006 to March, 2007 and October, 2008 to March, 2009 growing seasons. The soil type was silty loam, having pH 7.5 and $35 \%$ of field capacity.

The experiment was laid out in a split plot design with three replications. Each replicated field was divided into four main plots for sowing treatments $\left(S_{1}=18\right.$ October, $S_{2}=2$ November, $S_{3}=$ 17 November, $S_{4}=3$ December). Each main plot was divided into three sub-plots for varities of rapeseed. Each plot size was $4 \mathrm{~m} \times 3 \mathrm{~m}$, i.e., $12 \mathrm{~m}^{2}$ having a plot to plot distance $1 \mathrm{~m}$ to the NorthSouth, $2 \mathrm{~m}$ to the East-West; replication to replication distance $2 \mathrm{~m}$, row to row $30 \mathrm{~cm}$, and plant to plant $10 \mathrm{~cm}$ approximately. Border rows were not considered because of the border effect.

*Author for correspondence: <abdullah10bng@yahoo.com >. Institute of Biological Sciences, University of Rajshahi, Rajshahi-6205, Bangladesh. 
The most improtant stages like bud initiation, flowering, pod filling and physiological maturity were recorded in days when $50 \%$ of a variety of each replication reached a definite stage as the representative of that stage. The daily meteorological data from the Regional Meterotogical Office, located at about $1 \mathrm{~km}$ away from the experimental field, were used. The growing degreedays (GDD), heliothermal unit (HTU), phenothermal index (PTI) and heat use efficiency (HUE) were calculated according to the formulae of Rajput (1980).

Growing degree days $(G D D)=\left(T_{\max }+T_{\min }\right) / 2-T_{b}$ (Here, $T_{\max }=$ Maximum temperature, $T_{\min }$ $=$ Minimum temperature, $\mathrm{T}_{\mathrm{b}}=$ Base temperature $=10^{\circ} \mathrm{C}$ ).

Heliothermal unit $(\mathrm{HTU})=$ GDD $\times$ duration of sunshine hour, phenothermal index $(\mathrm{PTI})=$ GDD $\div$ growth days. Heat use efficiency $($ HUE $)=$ Grain yield $/$ ha $\div$ GDD .

\section{Results and Discussion}

The results of the present study indicated that delay in sowing decreased the time to attain different phenological stages (Table 1). The number of days taken for attainment of different phenological stages were in the order $S_{1}>S_{2}>S_{3}>S_{4}$. The $S_{1}$ plants took longest time followed by $\mathrm{S}_{2}, \mathrm{~S}_{3}$ and $\mathrm{S}_{4}$ which corroborates with the findings of Rajput et al. 1987, Paul and Sarker 2000, Haidar et al. 2003 in wheat, Dahiya and Narwal 1989 in maize and Alam et al. 2007 in barley. For each variety, a definite day was required to attain certain phenological stage of growth. Number of days for attainment of different phenological stages differed from variety to variety and the required days were decreased for every late sowings. Among the varieties, BINA Sarisha-5 required the highest number of days for attaining bud initiation, flower initiation, pod filling and physiological maturity followed by BINA Sarisha-6 and BARI Sarisha-14 (Table 2).

Table 1. Mean values of phenology (days after sowing) at different stages as affected by sowing dates (average of two seasons).

\begin{tabular}{lcccc}
\hline Sowing & Bud initiation & Flower initiation & Pod filling & Physiological maturity \\
\hline $\mathrm{S}_{1}(18$ October $)$ & 33.61 & 39.78 & 64.52 & 93.26 \\
$\mathrm{~S}_{2}$ (02 November) & 30.60 & 36.61 & 60.91 & 88.85 \\
$\mathrm{~S}_{3}(17$ November $)$ & 28.07 & 33.96 & 57.37 & 83.98 \\
$\mathrm{~S}_{4}(03$ December $)$ & 25.89 & 31.82 & 54.37 & 80.54 \\
LSD $(5 \%)$ & 1.03 & 1.06 & 1.20 & 1.58 \\
\hline
\end{tabular}

Table 2. Mean values of phenology (days after sowing) at different stages as affected by variety (average of two seasons).

\begin{tabular}{lcccc}
\hline Variety & $\begin{array}{c}\text { Bud } \\
\text { initiation }\end{array}$ & $\begin{array}{c}\text { Flower } \\
\text { initiation }\end{array}$ & $\begin{array}{c}\text { Pod } \\
\text { filling }\end{array}$ & $\begin{array}{c}\text { Physiological } \\
\text { maturity }\end{array}$ \\
\hline $\mathrm{V}_{1}$ (BARI Sarisha-14) & 27.82 & 33.93 & 46.98 & 78.75 \\
$\mathrm{~V}_{2}$ (BINA Sarisha-5) & 30.82 & 36.99 & 62.82 & 93.17 \\
$\mathrm{~V}_{3}$ (BINA Sarisha-6) & 29.96 & 35.71 & 58.09 & 88.06 \\
LSD (5\%) & 0.53 & 0.52 & 0.47 & 0.97 \\
\hline
\end{tabular}

The requirement of growing degree days (GDD) decreased with delayed sowing to different phenological stages are shown in Table 3. It was observed that higher GDD was required in $\mathrm{S}_{1}$ followed by $S_{2}, S_{3}$ and $S_{4}$ at all the phenological stages. On average, the $S_{1}$ plants required the heat units 485.77 for bud initiation, 554.90 for flower initiation, 802.72 for pod filling, 1020.70 for physiological maturity in the average of two years. So, the lowest heat unit requirement for all the 
phenological stages in all the varieties was observed in $\mathrm{S}_{4}$. Decreased GDD due to late sowing was reported by Rajput et al. 1987, Paul and Sarker 2000, Haidar et al. 2003 in wheat, Dahiya and Narwal 1989 in maize and Alam et al. 2007 in barley. Among the varieties, BINA Sarisha-5 obtained the highest heat unit for all the sowings at all the phenological stages and the lowest heat unit was found in BARI Sarisha-14 except pod filling. The GDD in BINA Sarisha-5 was 368.92 for bud initiation, 427.20 for flower initiation, 641.00 for pod filling and 917.24 for physiological maturity in the average of two years (Table 4).

Table 3. Mean values of GDD at different phenological stages as affected by sowing dates (average of two seasons).

\begin{tabular}{lcccc}
\hline Sowing & $\begin{array}{c}\text { Bud } \\
\text { initiation }\end{array}$ & $\begin{array}{c}\text { Flower } \\
\text { initiation }\end{array}$ & $\begin{array}{c}\text { Pod } \\
\text { filling }\end{array}$ & $\begin{array}{c}\text { Physiological } \\
\text { maturity }\end{array}$ \\
\hline $\mathrm{S}_{1}$ (18 October) & 485.77 & 554.90 & 802.72 & 1020.70 \\
$\mathrm{~S}_{2}$ (02 November) & 383.56 & 449.95 & 684.28 & 896.42 \\
$\mathrm{~S}_{3}$ (17 November) & 310.40 & 356.71 & 545.56 & 767.63 \\
$\mathrm{~S}_{4}$ (03 December) & 248.01 & 292.97 & 448.35 & 716.21 \\
LSD (5\%) & 9.27 & 9.02 & 56.03 & 27.84 \\
\hline
\end{tabular}

Table 4. Mean values of GDD at different phenological stages as affected by variety (average of in two seasons).

\begin{tabular}{lcccc}
\hline Variety & $\begin{array}{c}\text { Bud } \\
\text { initiation }\end{array}$ & $\begin{array}{c}\text { Flower } \\
\text { initiation }\end{array}$ & $\begin{array}{c}\text { Pod } \\
\text { filling }\end{array}$ & $\begin{array}{c}\text { Physiological } \\
\text { maturity }\end{array}$ \\
\hline $\mathrm{V}_{1}$ (BARI Sarisha-14) & 340.22 & 398.04 & 614.70 & 774.36 \\
$\mathrm{~V}_{2}$ (BINA Sarisha-5) & 368.92 & 427.20 & 641.00 & 917.24 \\
$\mathrm{~V}_{3}$ (BINA Sarisha-6) & 361.66 & 415.65 & 604.98 & 859.12 \\
LSD (5\%) & 5.73 & 6.00 & 1.89 & 14.19 \\
\hline
\end{tabular}

The helio-thermal units (HTU) at a definite phenological stage is the product of the length of sunshine hour of a day and the required accumulated heat units by plants. HTU for different phenological stages are presented in Table 5. Like GDD, HTU gradually decreased with delay in sowing. $S_{1}$ plants had the highest HTU for all the phenological stages followed by $S_{2}, S_{3}$ and $S_{4}$ in both the years. In $S_{1}$, the highest HTU was 3717.25 for bud initiation, 4282.74 for flower initiation, 5782.80 for pod filling and 6892.75 for physiological maturity in the average of two years (Table 5). Decreased HTU for different phenological stages due to delayed sowing were also reported by Rajput et al. 1987, Masoni et al. 1990, Bishnoi et al. 1995, Paul and Sarker 2000, Haidar et al. 2003 in wheat, Dahiya and Narwal 1989 in maize and Alam et al. 2007 in barley. Among the varieties, BINA Sarisha-5 had the highest HTU for all the sowings at all the phenological stages in average of two years and the lowest HTU was observed in BARI Sarisha14 for $\mathrm{S}_{4}$ at all the phenological stages. The attainment of HTU in BINA Sarisha-5 was 2618.43 for bud initiation, 2983.83 for flower initiation, 4120.62 for pod filling and 5661.64 for physiological maturity in the average of two years (Table 6).

Phenothermal index (PTI) of four sowing times are presented in Table 7. The phenothermal indices during sowing to bud initiation, flower initiation, pod filling and physiological maturity were in the order $S_{1}>S_{2}>S_{3}>S_{4}$. Phenothermal indices decreased with the advancement of plant age. It was also observed that PTI values in all the sowings were very close to one developmental phase to another developmental phase i.e., the results of PTI did not differ much between the 
developmental phases during the whole growth period (Table 7). Similar results were reported by Masoni et al. 1990, Bishnoi et al. 1995, Paul and Sarker 2000, Haidar et al. 2003 in wheat, Dahiya and Narwal 1989 in maize and Alam et al. 2007 in barley. Among the varieties, BARI Sarisha-14 attained the highest PTI in almost all the phenological stages except physiological maturity in BINA Sharisha-5 (Table 8).

Table 5. Mean values of helio-thermal unit at different stages as affected by sowing dates (average of two seasons).

\begin{tabular}{lcccc}
\hline Sowing & $\begin{array}{c}\text { Bud } \\
\text { initiation }\end{array}$ & $\begin{array}{c}\text { Flower } \\
\text { initiation }\end{array}$ & $\begin{array}{c}\text { Pod } \\
\text { filling }\end{array}$ & $\begin{array}{c}\text { Physiological } \\
\text { maturity }\end{array}$ \\
\hline $\mathrm{S}_{1}$ (18 October) & 3717.25 & 4282.74 & 5782.80 & 6892.75 \\
$\mathrm{~S}_{2}$ (02 November) & 2919.23 & 3357.84 & 4404.68 & 5703.09 \\
$\mathrm{~S}_{3}$ (17 November) & 2225.38 & 2439.56 & 3292.49 & 4586.25 \\
$\mathrm{~S}_{4}$ (03 December) & 1264.50 & 1522.69 & 2401.11 & 3974.84 \\
LSD (5\%) & 60.62 & 55.32 & 387.52 & 297.53 \\
\hline
\end{tabular}

Table 6. Mean values of helio-thermal unit at different stages as affected by variety (average of two seasons).

\begin{tabular}{lcccc}
\hline Variety & Bud initiation & Flower initiation & Pod filling & Physiological maturity \\
\hline $\mathrm{V}_{1}$ (BARI Sarisha-14) & 2413.69 & 2804.70 & 3867.20 & 4837.37 \\
$\mathrm{~V}_{2}$ (BINA Sarisha-5) & 2618.43 & 2983.83 & 4120.62 & 5661.64 \\
$\mathrm{~V}_{3}$ (BINA Sarisha-6) & 2562.65 & 2913.60 & 3922.99 & 5368.69 \\
LSD (5\%) & 32.53 & 31.34 & 10.00 & 118.79 \\
\hline
\end{tabular}

Table 7. Mean values of pheno-thermal index at different stages as affected by sowing dates (average of two seasons).

\begin{tabular}{lcccc}
\hline Sowing & $\begin{array}{c}\text { Bud } \\
\text { initiation }\end{array}$ & $\begin{array}{c}\text { Flower } \\
\text { initiation }\end{array}$ & $\begin{array}{c}\text { Pod } \\
\text { filling }\end{array}$ & $\begin{array}{c}\text { Physiological } \\
\text { maturity }\end{array}$ \\
\hline $\mathrm{S}_{1}(18$ October $)$ & 14.46 & 13.95 & 12.46 & 10.97 \\
$\mathrm{~S}_{2}$ (02 November) & 12.57 & 12.30 & 11.25 & 10.09 \\
$\mathrm{~S}_{3}(17$ November $)$ & 11.09 & 10.52 & 9.53 & 9.16 \\
$\mathrm{~S}_{4}(03$ December $)$ & 9.59 & 9.23 & 8.26 & 8.89 \\
LSD(5\%) & 0.24 & 0.14 & 0.92 & 0.20 \\
\hline
\end{tabular}

Table 8. Mean values of pheno-thermal index at different stages as affected by variety (average of two seasons).

\begin{tabular}{lcccc}
\hline Variety & $\begin{array}{c}\text { Bud } \\
\text { initiation }\end{array}$ & $\begin{array}{c}\text { Flower } \\
\text { initiation }\end{array}$ & $\begin{array}{c}\text { Pod } \\
\text { filling }\end{array}$ & $\begin{array}{c}\text { Physiological } \\
\text { maturity }\end{array}$ \\
\hline $\mathrm{V}_{1}$ (BARI Sarisha-14) & 12.06 & 11.59 & 10.69 & 9.78 \\
$\mathrm{~V}_{2}$ (BINA Sarisha-5) & 11.81 & 11.42 & 10.11 & 9.82 \\
$\mathrm{~V}_{3}$ (BINA Sarisha-6) & 11.91 & 11.49 & 10.32 & 9.72 \\
LSD (5\%) & 0.09 & 0.10 & 0.26 & 0.01 \\
\hline
\end{tabular}

The heat use efficiency (HUE) values were computed and are presented in Table 9. The $S_{1}$ plants used heat more efficiently than the plants of other sowings and the order was $S_{1}>S_{2}>S_{3}>$ $\mathrm{S}_{4}$. Similar results were also reported by Rajput et al. 1987, Paul and Sarker 2000 in wheat and 
Alam et al. 2007 in barley. The highest HUE was observed in BINA Sarisha-5 followed by BARI Sarisha-14 and BINA Sarisha-6 in average of two years. The lowest HUE was in BINA Sarisha-6.

Table 9. Mean values of heat use efficiency at different stages as affected by sowing dates and variety (average of two seasons).

\begin{tabular}{llll}
\hline Sowing & HUE & Variety & HUE \\
\hline $\mathrm{S}_{1}(18$ October $)$ & 0.96 & $\mathrm{~V}_{1}$ (BARI Sarisha-14) & 0.80 \\
$\mathrm{~S}_{2}(02$ November) & 0.95 & $\mathrm{~V}_{2}$ (BINA Sarisha-5) & 0.84 \\
$\mathrm{~S}_{3}(17$ November) & 0.65 & $\mathrm{~V}_{3}$ (BINA Sarisha-6) & 0.64 \\
$\mathrm{~S}_{4}(03$ December $)$ & 0.47 & LSD(5\%) & 0.08 \\
LSD $(5 \%)$ & 0.07 & & \\
\hline
\end{tabular}

The results of the present study suggest that changes in the ambient temperature for a short period are reflected in the phenothermal index during the individual growth stages. Thus, the index seems to be effective in taking into account and expressing the effect of varying ambient temperature on the duration between the phenological events for comparing the crop response to the ambient temperature between the different phenological stages. The difference in phenothermal indices for different growth stages indicates that the accumulated temperature could be utilized for studying biomass accumulation pattern at different phenological stages which ultimately influences the crop productivity.

\section{References}

Alam MZ, Haider SA and Paul NK 2007. Influence of sowing date and nitrogen fertilizer on the phenology and accumulated heat units in barley. Plant Environ. Dev. 1(2): 75-81.

Bishnoi OP, Singh S and Niwas R 1995. Effect of temperature on phenological development of wheat (Triticum aestivum L.) Indian J. Agric. Sci. 65: 211-214.

Chakravarty NVK and Sastry PSN 1983. Phenology and accumulated heat unit relationships in wheat under different planting dates in the Delhi regions. Agric. Sci. Prog. 1: 32-42.

Dahiya DS and Narwal SS 1989. Effect of sowing date on phenology and growing degree day requirement of winter maize (Zea mays L.). Indian J. Agric. Sci. 59: 589-592.

Haider SA, Alam MZ, Alam MF and Paul NK 2003. Influence of different sowing dates on the phenology and accumulated heat units in wheat. J. Biol. Sci. 3(10): 932-939.

Masoni A, Ercoli L and Massantini F 1990. Relationship between number of days, growing degree days and phenothermal units and growth of wheat (Triticum aestivum L.) according to seeding time. AgriculturaMediterrancea. 120: 41-51.

Paul NK and Sarker DK 2000. Accumulated heat units and phenology relationships in wheat as influenced by sowing dates. Bangladesh J. Bot. 29: 45-54.

Phadnawis NB and Saini AD 1992. Yield models in wheat based on sowing time and pheonological development. Annals Plant Physiology.6 (1): 52-59.

Rajput RP, Deshmukh MR and Paradkar VK 1987. Accumulated heats unit and phenology relationships in wheat (Triticum aestivum L.) as influenced by planting dates under late-sown condition. J. Agron. \& Crop Sci. 159: 345-348.

Rajput RP 1980. Response of soybean crop to climatic and soil environments. Ph.D. Thesis. IARI, New Delhi, India.

Tewari, SK and Sing M 1993. Yielding ability of wheat at different date of sowing - a temperature development performance. Indian J. Agron. 38(2): 204-209. 